\title{
ENKRIPSI KONTEN BLOB-FIELD UNTUK PENGAMANAN DATA BANK SOAL UJIAN CBT (Computer Based Test)
}

\author{
Juli Rejito ${ }^{1)}$, Deni Setiana ${ }^{2)}$ \\ E-mail : 1)jrejito@gmail.com, ${ }^{2)}$ denisetiana@gmail.com \\ Program Studi Teknik Informatika, Departemen Ilmu Komputer \\ FMIPA, Universitas Padjadjaran
}

\begin{abstract}
Implementation of information technology especially in CAT (Computer-Assisted Test) started being used. Confidentiality matter stored in database becomes the main thing that must be considered, because the questions used in test should not be publicized (leak) both from test participants (clients) as well as from a database manager (administrator). In this paper will be presented one alternative security solutions matter stored in BLOB-field database that contains encoded image, so the original content that matter will only be read when using the actual application. Technical encryption used to take advantage of symmetric encryption that is raised in the application form entry question bank as tools incorporate a matter also functions for encryption of content matter, on the other hand use applications CAT used by user to work also functions as the decrypted content question. Proof about the encryption result is shown with direct access into BLOB-field matter content stored in the database using database access interface.
\end{abstract}

Keywords: CAT (Computer Assisted Test), BLOB fields, encryption, database, question bank

\begin{abstract}
ABSTRAK
Implementasi teknologi informasi khususnya dalam ujian berbasis komputer (CAT-Computer Assisted Test) mulai banyak digunakan. Kerahasiaan soal yang tersimpan dalam bentuk database menjadi hal utama yang harus diperhatikan, dikarenakan soal yang dipergunakan dalam ujian tidak boleh terpublikasikan (bocor) baik dari sisi peserta test (client) yang menggunakan cat tersebut maupun dari pengelola database (administrator). Dalam paper ini akan dipaparkan salah satu alternative solusi pengamanan soal yang tersimpan dalam bentuk blob-field database yang memuat konten teks maupun konten citra yang disandikan, sehingga konten soal yang aslinya hanya akan terbaca apabila menggunakan aplikasi cat yang sesungguhnya. Teknis penyandian yang dipergunakan dalam blob-field adalah dengan memanfaatkan enkripsi simetrik yang dimunculkan dalam bentuk aplikasi entry bank soal sebagai alat bantu memasukkan soal sekaligus berfungsi untuk enkripsi konten soal, disisi lain menggunakan aplikasi CAT yang dipergunakan oleh user untuk mengerjakan soal sekaligus berfungsi sebagai dekripsi konten soal. Pembuktian hasil enkripsi soal ditunjukkan dengan akses langsung ke dalam blob-field konten soal yang tersimpan pada database menggunakan antar muka akses database.
\end{abstract}

Kata kunci : CAT (Computer Assisted Test), blob field, enkripsi, database, bank soal 